\title{
Research on Teaching Reform of Universities and Colleges in China - In the Perspective of Education Informatization
}

\author{
Minhua $X u^{1, a}$ \\ ${ }^{1}$ Economic Management Institute, Jilin Agricultural University, Changchun, 130118, China
}

Keywords: College teaching; College management; Teaching informatization; Teaching resources

\begin{abstract}
Under big data and education informatization environment, college teaching management informatization has new characteristics and developing direction. Facing with the challenge of the information age, colleges and universities not only must carry on the education innovation, but also innovate of the teaching, scientific research management. It is to build a new and more effective model of resource integration. University informatization carry the advantage of the advanced science and technology, in promoting university education concept, education system, teaching management, teaching means and methods of education of fundamental change at the same time, Effectively promote the development of higher education. Combining with the implementation of the teaching management in colleges and universities information process and conditions, we base on the current situation of the teaching management informationization, the existence question and the innovation requirements, and modern teaching management based on the study of effective integration, aim at innovating ideas of teaching management informatization, and explore a new way of teaching management informatization.
\end{abstract}

\section{Introduction}

With the development of information technology, education department explicitly offered to drive the modernization of education by information technology. Informatization level of teaching management is related to the quality and efficiency of college of education and occupies important position in the work of colleges and universities. Teaching management informatization is the trend of the development of The Times, and teaching management also should be actively realize self transformation, so to realize comprehensive universities teaching management informatization. This paper analyzes the basic content of the teaching informatization, then on the basis of college teaching informatization related measures are put forward, in order to designed to help better realize the informationization teaching.

\section{Teaching management informationization connotation}

The so-called teaching management informationization means in the process of comprehensive teaching management informatization, the widely uses modern information technology, and improve the comprehensive teaching management efficiency. Teaching informatization is a process of education modernization and education development.

With the continuous development of science and technology, Comprehensive teaching management in colleges and universities information also has obtained certain achievement, but due to the comprehensive teaching management informatization in China starts late, the difficulties needed to be conquered is more. So, we must take targeted measures to promote the comprehensive teaching management in colleges and universities information process[1].

\section{Overview of information education in colleges and universities}

First ,the necessity of the reform. Teaching informatization in colleges and universities put forward the corresponding requirements, one is infrastructure requirements, the basic connotation of 
information technology is the use of modern science and technology, this requires colleges and universities must carry out related infrastructure construction. Infrastructure construction is divided into two aspects: on the one hand is to computer hardware, such as construction, on the other hand is for the construction of the campus network. Both complement each other, the infrastructure construction will do a good job only, so it is possible for the comprehensive teaching management informatization construction. Second, the teaching information is required for the construction of information system. So information management system is the necessary way to realize informatization management[2].

Therefore, under the background of big data, colleges and universities teaching information construction is imminent.

Second, teaching management informatization has problems in the following: the standardization of the information resources construction, the development of teaching management information system, localization aspect of teaching management system, the construction of teaching management team,

finally, ICT and teaching management integration is not harmonious.

Third, the new requirements of modern management in universities.

Teaching modernization mainly emphasized on new technology and new method to reform the basis for decision making. The key to the modern decision-making work is the foundation of realization of management function. Realization of modernized management of colleges and universities need to develop scientific decision system, need a complete decision-making process and a scientific and reasonable development of network information platform, and it is a process from the traditional information processing of the processing of the development of information technology. School teaching information technology is not only school management, but also provide for the development of the school knowledge management such as transmission provides direction. The construction of the campus information system may be comprehensively analyzed through the campus integrated operation condition, thus to improve the decision-making of the leadership and the improvement of the service work for students[3].

\section{The countermeasures of pushing forward informationalization of teaching}

The innovation of teaching informationization of teaching management is put forward based on the requirements, facing with the challenge of the information age, with advanced scientific and comprehensive system of teaching management new concept as the guide, pay attention to management innovation, reform and improve the routine teaching management, the establishment of the environment of information management, strengthening the construction of teaching management team is an effective measure to improve teaching management informatization[4].

First , the reform of teaching concept

Teachers use information technology teaching, training students' collecting, analyzing, sharing, judgment and the ability to use information and promote their autonomous learning ability and innovation ability. The relationship between teachers and students becomes natural transition and transformation in the process, the students become the masters of the classroom and participants, teachers grasp the direction of the classroom, knowledge comb, achieve the purpose of imparting knowledge to students and improve students' ability through the guidance and.

Second, the reform of the teaching means

On the one hand, teachers create learning situations, the demonstration experiment process, teaching resources, communication with students through the information technology. This a series of changes exerts a subtle influence on cultivating the students' information consciousness and the flexible class organization form, broadening the channels for the students to learn, enrich the teaching resources, is the university classroom beneficial change

On the other hand, with the application of information technology in the classroom, it promotes the development of the multimedia teaching design theory research, conveniences for the 
development of multimedia network teaching resources and restructures, greatly improves the teaching level.

Third, the improvement of teachers' quality

Information-based teaching environment on university teachers put forward higher requirements:

Teachers must constantly improve their professional knowledge level;

Teachers must constantly improve their level of education theory and teaching practice, set up the new teaching concept, using new teaching methods and means, improve the quality of teaching and classroom efficiency;

Teachers must constantly improve their level of information technology, the information consciousness, improve access to information, process information and the ability to use information, and on this basis, strengthen the development and utilization of teaching resources, use information technology innovation education in colleges and universities[5].

Forth, improve the relevant rules and regulations of teaching management informatization

According to the college's own reality, we should system research to regulate, tight, strong operability, to satisfy the needs of the informationization teaching management rules and regulations, achieve the standardization of teaching management and sequencing. We Should make full use of existing resources in the construction of the data center and application software, good education informatization construction hardware environment, set up is given priority to with faculty management system of teaching management. And we according to the needs of the reform and development in colleges and universities, revise, improve and enrich the rules and regulations, to ensure the rationality of the system for the unification of the rigor and teaching information management system timely[6].

Fifth, completes the teaching planning and design of management information system, to ensure the scientific nature of the teaching management informationization

When planning the whole information system, not only we should study and research of domestic colleges and universities in this respect, but also should draw on the successful experience of foreign universities in this respect. Guiding by the modern education thought, we should reasonable plan, overall arrange, manage software development and collect teaching information. Universities in their own internal knowledge and technical resource advantages, combined with the enterprise development platform, organization of specialized management and technical personnel and enterprise cooperation, the development of personalized teaching management system software.

Sixth, information integration and sharing of teaching resources

University department of information resources should be effectively integrated and shared. We should set up schools and departments at all levels of resource database, through the standardization management of the teaching management information system of open all kinds of information resources for teachers and students' queries. We should strengthen the powers of the query set and protection, adopt various incentives to encourage teachers and management personnel, technical personnel development and production of standard, standardization of information resources, the construction of electronic teaching materials and courseware, academic literature database, database management, such as for the integration of information resource, building a batch of media material database, project learning website, professional repository. The development and construction of information resources should follow a unified standard, so that information sharing and utilization[7].

Seventh, the reform of students and the management pattern training mode

In today's education informatization environment, on the basis of update education concept, namely we should reform of colleges and universities personnel training mode, establish the diverse talent, adopt various training methods, according to their aptitude, create a good environment for the growth of diverse talents.

Eighth, the improvement of the evaluation system

Under the information environment, the traditional examination pattern evaluation system have obviously cannot adapt to the demand of teaching, we should be based on information 
technology, establish a new evaluation system, makes every effort to give students an objective, comprehensive and reasonable assessment, and implement evaluation promotes step, the purpose of promoting development, promote the increase.

First of all, we have to pay attention to the implementation process and the result of combining the evaluation model. Teachers use information technology for the process of learning for students throughout the semester record, set up electronic file cover, on the one hand, to find the problems existing in the students in the learning process, problems or deviation, and properly solve, on the other hand, the comprehensive objective evaluation on the students. The teacher to student daily performance combined with a final grade, form the final evaluation of students.

Second, we should realize the combination of quantitative and qualitative evaluation model, detailed evaluation standard and flexible evaluation form, obtaining objective and fair evaluation result.

Finally, the teacher wants to enrich evaluation main body, should abandon the traditional teacher qiankun "a set of evaluation model, teachers and students realize self-evaluation of students, students mutual, mutual combination of diversified evaluation mode, achieve the goal of teaching is learning and improving.

\section{Conclusion}

With the application of modern information technology in college teaching management, teaching management informatization has received the widespread attention. College teaching management informatization, is the automation of high and new technology and method of implementation of press close to The Times and the development of teaching management. The management of the information age, it is a kind of around the work target of information communication and target management, it implements the management system and technology real close 2 for one, puts forward new requirements for quality of administrators, also drove the structure change of the management. Therefore, urgent need for innovation in the teaching system, fully arouse the enthusiasm of the faculty, to adapt the demand of informatization, really to do a good job of teaching of colleges and universities.

\section{References}

[1] Zhi-he Yang. Cloud computing: the transformation of the education informationization booster [J]. Journal of China education informatization,2010(05).

[2]Zhi Ming Yan, Shichun Wang, Xiangwei Kong. Diffusion of innovation of education informatization research [J]. Journal of Chinese audio-visual education,2008.

[3] Pengfei Gao.The informationization teaching quality evaluation research [D]. Nanjing: nanjing normal university,2011.

[4] Qing-hua Qiu, Shao-yun Deng, etc. The application of multimedia technology in college teaching and thinking [J]. Journal of Tribune, in economic research,2009(24).

[5] Weijun Wang.Teachers' information technology teaching ability development research [D]. Northwest normal university,2009.

[6]Fengmin Chen, Ying-zhi Li, Tian Luo. Campus financial informationization and modernization of management of colleges and universities to study [J]. Value engineering.2010 (5).

[7] Lei Cheng. The teaching practice of information management research [J]. Journal of huaihai institute of technology (humanities and sociology).2013 (22) 